\title{
ANALISIS CUSTOMER PATH 5A PADA SPONSOR FILM AADC 2 SEBAGAI PROGRAM ENTERTAINMENT BRANDING
}

\author{
Elisabeth Nathasha H. Tampi ${ }^{1}$, Indra Novianto Adibayu Pamungkas ${ }^{1}$ \\ ${ }^{1}$ Universitas Telkom
}

\begin{abstract}
ABSTRAK
Customer Path merupakan hal yang sering dilupakan oleh pelaku marcomm ketika akan menentukan tools yang tepat untuk memasarkan produk atau jasa. Jika jenis industrinya berbeda, tentu customer path yang terbentuk akan berbeda. Sebelum hadirnya era konektivitas seperti sekarang ini, customer path yang hadir adalah Aware, Attitude, Act dan Act Again. Konsumen dianggap akan melakukan pembelian ulang jika sebelumnya sudah melakukan pembelian. Namun, di era konektivitas seperti sekarang ini, tolak ukur keberhasilan ternyata bukan hanya diukur dari pembelian berkala. Tidak semua industri akan mengalami pembelian berkala dalam kurun waktu singkat. Salah satu hal yang menjadi tolak ukur baru adalah Advocate atau tahap merekomendasikan kepada orang lain. Sehingga customer path yang terbentuk menjadi customer path $5 A$ yang terdiri dari Aware, Appeal, Ask, Act dan Advocate. Peneliti mencoba untuk menganalisis customer path $5 A$ yang terbentuk dari kehadiran program entertainment branding film Ada Apa Dengan Cinta 2. Pada penelitian ini, peneliti menggunakan paradigma konstruktivisme dengan metode penelitian kualitatif. Sebelumnya, peneliti juga melakukan pra-riset untuk menyaring informan yang tidak menonton Ada Apa Dengan Cinta 1. Selanjutnya peneliti mengolah hasil wawancara dari 3 informan utama dan 2 informan pendukung. Hasil dari penelitian ini adalah bahwa program entertainment branding ini kurang berhasil mengingat 3 informan utama kurang tertarik pada 9 merek sponsor, terlebih lagi tidak ada identical product yang menjadi khas. Hasil lain menunjukkan bahwa informan utama lebih sadar dengan adanya destination branding yang terjadi secara sengaja ataupun tidak sengaja.
\end{abstract}

Kata-kata Kunci: Customer Path, AADC 2, Sponsor Film, Merek, Entertainment Branding.

\section{ANALYSIS ON CUSTOMER PATH 5 A FOR AADC 2 FILM SPONSORSHIP AS ENTERTAINMENT BRANDING PROGRAM}

\begin{abstract}
Customer Path is often forgotten by marcomm offender when determining the right tools to market your products or services. If a different type of industry, of course customer path that is formed will be different. Before the presence of this current era of connectivity, customer path is Aware, Attitude, Act and Act Again. Consumers considered will make repeat purchases if you have already made a purchase. However, in today's era of connectivity, measure of the success was not only measured by periodical purchases. Not all industries will experience periodic purchases in a short span of time. One of the things that become a new benchmark is the stage Advocate or recommend to other people. So the customer path formed into customer path 5 A consisting of Aware, Appeal, Ask, and Advocate Act. Researchers tried to analyze customer path $5 \mathrm{~A}$ formed by the presence entertainment branding program of Ada Apa Dengan Cinta 2 film. In this study, researchers used a constructivism with qualitative research methods. Previously, researchers also conducted a pre-research to filter informants who did not watch Ada Apa Dengan Cinta 1. Furthermore, researchers process the results of three key informants' interviews and two supporter informants. Results from this study is that the entertainment branding program was less successful remember three key informants were less interested in 9 brands sponsor, moreover, there is no identical product that became typical. Other results showed that the main informant more conscious with their destination branding that happened intentionally or unintentionally.
\end{abstract}

Keywords: Customer Path, AADC 2, Film Sponsorhip, Brand, Entertainment Branding.

Korespondensi: Elisabeth Nathasha H. Tampi. Universitas Telkom, Jl. Telekomunikasi, Sukapura, Dayeuhkolot, Bandung 40257.Email: enhtampi@gmail.com 


\section{PENDAHULUAN}

Kebutuhan hidup manusia semakin hari semakin mengingkat termasuk pada kebutuhan hirarki nya. Tingkat kebutuhan hidup manusia semakin hari semakin berkembang selaras dengan perkembangan kemajuan tingkat dan pola konsumsi masyarakat Kebutuhan manusia terdiri dari kebutuhan primer, sekunder dan tersier. Namun, dengan semakin berkembangannya zaman, kebutuhan manusia bukan hanya segala sesuatu yang nampak, namun juga yang tak nampak. Kebutuhan masyarakat akan informasi juga sangat berkembang pesat. Hal ini juga berdampak pada kebutuhan manusaia akan hiburan. Dengan adanya situasi ini, secara tidak langsung, manusia dituntut untuk dapat mengetahui informasi yang sedang terjadi di lingkungan sekitar kita baik skala nasional maupun internasional. Data yang dikutip dari survey Google Trends menunjukkan bahwa 10 penelusuran terpopuler Google berada pada kategori hiburan (Sumber : https://www. google.co.id/trends/topcharts / diakses pada tanggal 5 Agustus 2016 jam 23:14 WIB).

Kehidupan manusai kini semakin mobile. Tuntutan dunia kiri mengharuskan manusia harus "24 hours ready" Perilaku manusia kiri menuntut anytime accessable dan hal ini terbukti dimana masyarakat Indonesia yang tinggal di kota besar, 24 jam waktu sudah dihabiskan untuk bekerja. Saat memasuki weekend, tentu yang dicari adalah hiburan apa yang bisa menghilangkan kejenuhan mereka akan aktivitas sehari-hari. Hiburan termasuk kebutuhan yang berhubungan dengan pemenuhan hasrat . Tentu saja cara pemenuhannya pun beragam, mulai dari travelling ke luar kota, berkeliling pusat berbelanjaan, hingga menghabiskan akhir pekan dengan menonton film yang baru tayang di bioskop di Indonesia.

Melakukan kegiatan untuk tujuan hiburan seperti menonton di bioskp bukan lagi terbatas untuk kalangan remaja saja melainkan untuk semua kalangan.. Para karyawan hingga keluargapun, seringkali memilih untuk menghabiskan waktu mereka dengan menonton film baik menonton dirumah ataupun berburu tiket menonton film di bioskop. Kini, dengan semakin banyaknya pilihan bioskop di berbagai lokasi, masyarakat Indonesia semakin dimanjakan dengan kemudahan tersebut. Tercatat hingga bulan Juli 2016, jumlah penonton film Indonesia di bioskop mencapai angka 16 juta orang. Angka ini merupakan angka tertinggi sejak tahun 2009, padahal tahun ini baru di pertengahan tahun. Bukan waktu sebentar untuk mengembangkan film Indonesia (Sumber

https://www.cnnindonesia.com/hiburan/201607 29000615-220-147779/jumlah-penonton-filmindonesia-tertinggi-setelah-enam-tahun diakses pada tanggal 6 Agustus 2016 jam 10:32 $W I B)$. Dengan meningkatnya jumlah penonton film Indonesia terutama di bioskop, tentu ini menjadi salah satu indikator dari meningkatnya kualitas perfilman di Indonesia.

Sejak hadirnya film pertama pada tahun 1920-an, dunia perfilman Indonesia mengalami 
ProTVF, Volume 2, Nomor 1, Maret 2018, Hal. 69-86

naik turun baik dari segi kualitas ataupun kuantitas. Terlebih lagi saat masuknya masa orde lama yang membuat perfilman Indonesia semakin krisis dalam hal pendanaan. Namun,

\begin{tabular}{|c|l|c|}
\hline 8 & Gie & 2005 \\
\hline 9 & Si Doel Anak Betawi & 1973 \\
\hline 10 & Petualangan Sherina & 1999 \\
\hline
\end{tabular}

Sumber : http://blog.unsri.ac.id/ titik balik terjadi di tahun 2000 dimana industri perfilman Indonesia mulai belajar dari kesuksesan banyak film Hollywood yang tidak hanya berjaya di negaranya namun juga banyak yang masuk ke Indonesia. Beberapa kali perfilman Indonesia sempat dilanda krisis ide dengan hanya menampilkan cerita horor berbalut "cerita dewasa", namun beberapa tahun belakangan ini Indonesia kembali menunjukkan eksistensi dengan menghadirkan film-film bioskop yang berkelas dan mampu bersaing dengan film internasional lainnya.

Perkembangan positif yang dirasakan dunia perfilman Indonesia, ternyata juga berdampak baik bagi beberapa bidang lainnya. Salah satunya yakni film digunakan sebagai salah satu media atau alat penyampaian pesan kepada masyarakat luas. Praktisi dibidang pemasaran dan branding memanfaatkan film sebagai salah satu media untuk branding beberapa merek yang menjadi sponsor dari film tersebut.

Tabel 1.1

10 Film Indonesia Terbaik Sepanjang Masa

\begin{tabular}{|c|l|c|}
\hline Rank & \multicolumn{1}{|c|}{ Film } & Tahun \\
\hline 1 & Laskar Pelangi & 2008 \\
\hline 2 & Tjoet Nja Dhien & 1986 \\
\hline 3 & Naga Bonar & 1986 \\
\hline 4 & Ada Apa Dengan Cinta & 2002 \\
\hline 5 & $\begin{array}{l}\text { Kejarlah Daku Kau } \\
\text { Kutangkap }\end{array}$ & 1985 \\
\hline 6 & Badai Pasti Berlalu & 1977 \\
\hline 7 & Arisan & 2003 \\
\hline
\end{tabular}

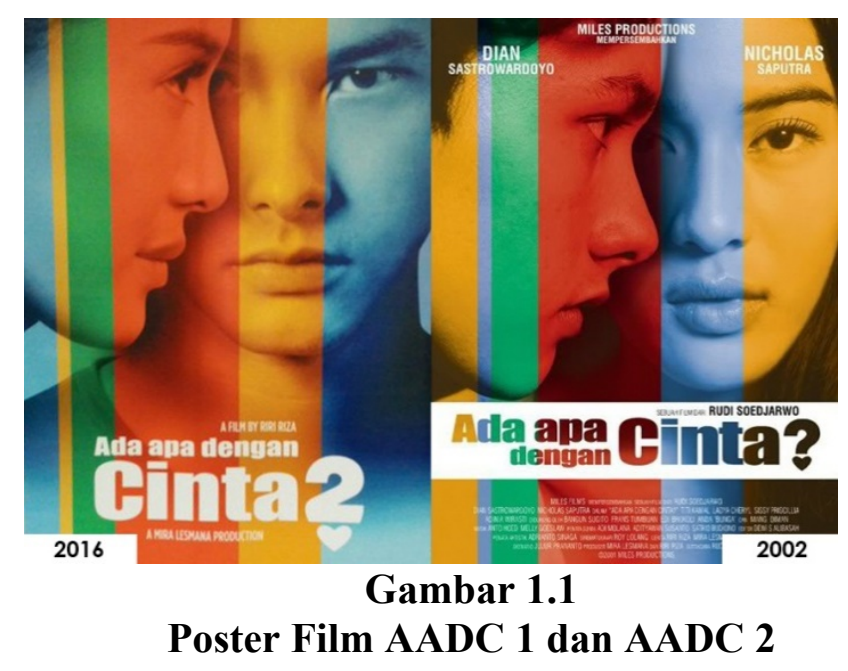

Sebagai film yang masuk dalam 10 besar film Indonesia terbaik sepanjang masa, film Ada Apa Dengan Cinta berhasil mencuri perhatian dan kenangan bagi banyak penikmatnya. Film Ada Apa Dengan Cinta adalah film Indonesia karya sutradara Rudi Soedjarwo dan diproduseri oleh Mira Lesmana dan Riri Riza mengangkat tentang kisah percintaan dan kehidupan SMA remaja kala itu yang dibintangi oleh Nicholas Saputra dan Dian Sastrowardoyo. Dibawah naungan Miles Films, film ini dilengkapi dengan lagu tema dengan judul sama yang dibawakan oleh Melly Goeslaw dan Eric yang menjadi hits hingga sekarang. Ketenaran film zaman 2002 tidaklah semudah zaman sekarang yang sudah dimudahkan dengan teknologi. Ada Apa Dengan Cinta 1 yang kemudian disebut AADC 1 menjadi fenomenal berkat cerita yang diangkat yang menjadi trendsetter bagi remaja masa itu. Dikutip dari salah satu situs berita 
online Indonesia, setidaknya ada lima hal dari film AADC 1 yang menjadi panutan remaja era 2002 bahkan kenangan hingga masa kini. Pertama, kisah persahabatan erat antara Cinta (Dian Sastrowardoyo), Maura (Titi Kamal), Alya (Ladya Cherill), Carmen (Adinia Wirasti) dan Milly (Sissy Pricillia) yang akhirnya menginspirasi hadirnya istilah genk di kalangan remaja. Kedua, daerah Kwitang Senen yang menjadi salah satu latar tempat film AADC 1, dimana akhirnya menjadi tempat bagi remaja masa itu untuk mencari buku buku murah. Ketiga, buku Aku karya Chairil Anwar menjadi popular karena ini puisi dengan judul yang sama juga dibawakan oleh Rangga (Nicholas Saputra) saat beradegan di film AADC 1. Keempat, beberapa dialog atau kalimat yang diungkapkan seakan bisa digunakan dalam percakapan sehari hari seperti "Pecahkan saja gelasnya biar ramai" atau "Lalu salah siapa? Salah gue? Salah teman teman gue?".

Kelima, sudah pasti diingat adalah adegan perpisahan Rangga dan Cinta saat di bandara yang menjadi akhir dari film sekaligus penantian para penikmatnya.

Penantian penikmat film Indonesiapun terjawab. Sejak akhir 2015 lalu sudah bermunculan iklan yang menunjukkan bahwa Miles Films akan memproduksi film Ada Apa Dengan Cinta 2 yang kemudian disebut dengan AADC 2. Tentu masyarakat Indonesia penasaran karena selama 14 tahun akan memberikan perubahan yang begitu besar bagi kisah Rangga dan Cinta dalam film ini. Film AADC 2 resmi tayang pada tanggal 28 April
2016 tidak hanya di Indonesia, namun juga di beberapa negara di Asia Tenggara.

Tabel 1.2

10 Film Indonesia Dengan Jumlah Penonton Tertinggi Tahun Edar Film 2016

\begin{tabular}{|c|l|c|}
\hline No & \multicolumn{1}{|c|}{ Film } & $\begin{array}{c}\text { Jumlah } \\
\text { Penonton } \\
\text { (juta) }\end{array}$ \\
\hline 1 & Ada Apa Dengan Cinta 2 & 3.665 .509 \\
\hline 2 & My Stupid Boss & 3.052 .657 \\
\hline 3 & \{rudy habibie\} & 1.974 .140 \\
\hline 4 & $\begin{array}{l}\text { Comic } 8: \text { Casino Kings } \\
\text { Part 2 }\end{array}$ & 1.835 .644 \\
\hline 5 & Koala Kumal & 1.794 .192 \\
\hline 6 & ILY from 38.000 Ft & 1.521 .766 \\
\hline 7 & London Love Story & 1.124 .876 \\
\hline 8 & Sabtu Bersama Bapak & 638.749 \\
\hline 9 & Talak 3 & 567.917 \\
\hline 10 & Modus & 382.342 \\
\hline
\end{tabular}

Tak perlu waktu lama, film AADC 2 pun berada di peringkat pertama sebagai film Indonesia terlaris di sepanjang pertengahan tahun 2016 dengan total 3,7 juta penonton. Sejak awal kemunculan trailernya di dunia maya ataupuan di televisi, AADC 2 sudah mampu membangkitkan kenangan lama masyarakat Indonesia yang sebelumnya sudah menyaksikan film AADC 1 pada masa tayangnya yakni tahun 2002 .

Jumlah penontonnya berada di angka 3,7 juta penonton ini adalah angka yang menggabungkan antara penonton yang sudah menonton AADC 1 pada tahun 2002 ataupun yang baru menonton dengan penonton yang tidak mengikuti cerita AADC sedari awal. Untuk membuktikan hal tersebut, peneliti melakukan pra-penelitian dengan menyebarkan 
kuesioner kepada 100 orang responden dengan kriteria responden harus sudah menonton film AADC 2. Dari kuesioner yang disebar, maka peneliti mendapatkan rangkuman jawaban sebagai berikut.

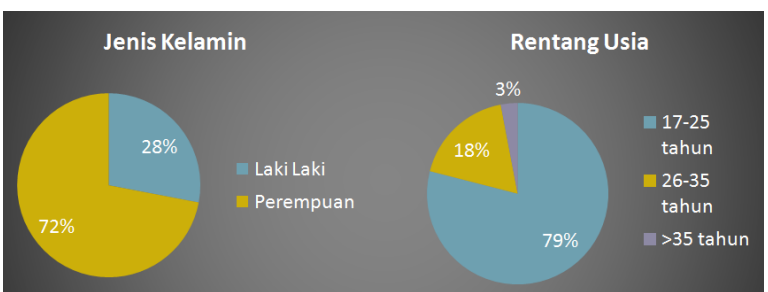

Gambar 1.2

Data Responden

Data diatas adalah menunjukkan data responden kuesioner pra-penelitian. Dari 100 responden, $72 \%$ adalah perempuan dan sisanya adalah laki-laki. Sebanyak 79\% responden berusia di rentang 17-25 tahun, 18\% di rentang usia 26-35 tahun dan sisanya berusia lebih dari 35 tahun. Hal ini menunjukkan bahwa sebagian besar responden tergolong pada usia remaja akhir beranjak dewasa.

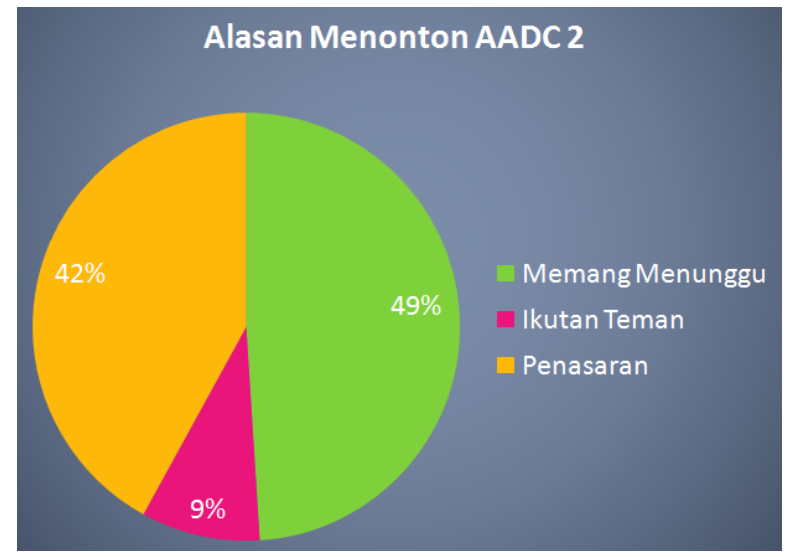

Gambar 1.3

Alasan Menonton AADC 2

Sebanyak 100 responden yang semuanya telah menonton film AADC 2, ternyata memiliki alasan masing-masing. 49\% menonton AADC 2 karena memang menunggu kelanjutan dari ceritanya sebelumnya, $42 \%$ menonton karena rasa penasaran dan sisanya menonton karena mengikuti keinginan teman saja.

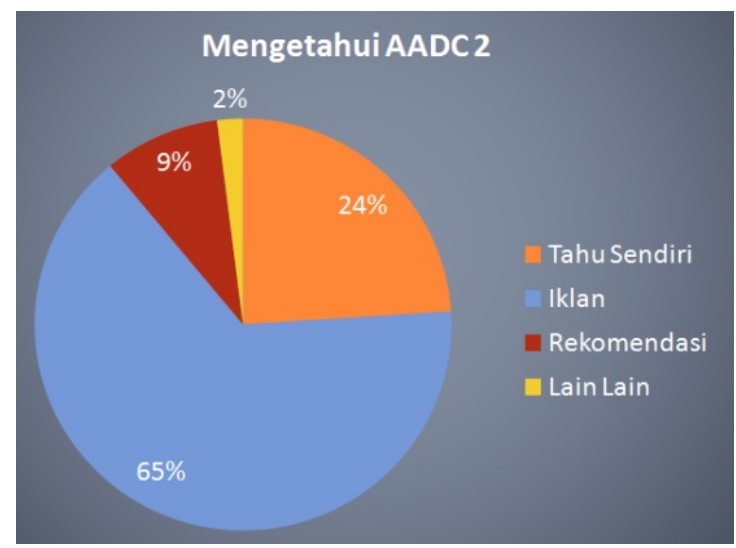

Gambar 1.4

Jenis Iklan AADC 2

Medium yang digunakan untuk mengetahui film AADC 2 ternyata berbeda beda. $65 \%$ responden mengaku mengetahui film AADC 2 dari iklan. Dari 65 responden tersebut, 51 diantaranya melihat dari iklan sosial media, 9 responden melihat dari iklan TV dan 2 responden melihat dari iklan di bioskop. 35\% responden terbagi ke dalam kategori pengetahuan akan diri sendiri, rekomendasi orang lain, dan berbagai medium lainnya yang tidak disebutkan dalam kuesioner.

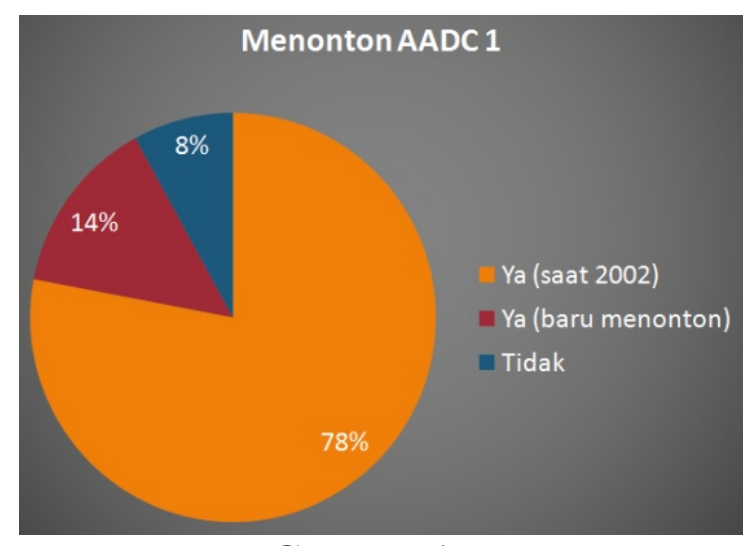

\section{Gambar 1.5 Penonton AADC 1}

Ketika ditanya apakah 100 responden yang menonton AADC 2 ini menonton AADC 1 juga, maka jawabannya pun sangat bervariasi. $78 \%$ responden mengaku sudah menonton saat 
AADC 1 pertama kali tayang tahun 2002. 14\% menonton saat mengetahui akan ada kelanjutan ceritanya dan $8 \%$ responden mengaku tidak menonton AADC 1. Hal ini tentu sangat unik mengingat dua film ini merupakan film yang berkelanjutan. Jika ada responden yang tidak menonton cerita awal namun menonton film kelanjutannya, tentu ada hal lain yang membuat responden ingin menonton AADC 2.

Film ini ternyata tidak hanya fenomenal dari sisi cerita yang membangkitkan kerinduan di era 2002, namun dari segi promosi dan pemasarannya tak kalah menarik. Dilansir dari Majalah SWA edisi XXXII/23 Juni - 10 Juli 2016, artikel 'AADC 2, Keampuhan Pemasaran Digital' hasil wawancara dengan Riri Riza dan Mira Lesmana, AADC 2 adalah salah satu bukti bahwa pemasaran film juga bisa mengoptimalkan kecanggihan teknologi dan pemasaran digital. Dari sisi sponsor, AADC 2 didaulat sebagai film Indonesia dengan sponsor terbanyak. Setidaknya ada 9 merek yang berhasil bekerjasama dengan Miles Films yaitu Aqua dan L'oreal yang hadir sebagai sponsor utama, lalu didukung oleh LINE, Lenovo, dan partner sponsor lainnya seperti Magnum, Mitsubishi, Garuda Indonesia, Telkomsel dan Fuji Film. Sejak resmi diumumkannya pada bulan Maret 2015, tim pemasaran, komunikasi dan digital dari AADC 2 sudah membuat konsep pemasaran yang sangat spesifik. Selain mendukung melalui promosi, Sembilan merek ini hadir pada insertion film di sepanjang alur cerita AADC 2.
Jarak 14 tahun dengan AADC 1, membuat sekuelnya kini memiliki dua target yang berbeda. Menurut Mira Lesmana, target pertama tentu generasi milenial yang lahir di tahun 1982-2000. Sedangkan target kedua adalah, generasi yang lahir setelahnya dan memiliki rasa penasaran dengan film AADC ini. Bagi pihak Miles Films, cara insertion film ini dianggap ampuh untuk membentuk brand sustaining serta eksistensi di kalangan antar generasi. Seperti yang diketahui, delapan dari sembilan sponsor yang telah disebutkan adalah merek yang sudah lama ada di Indonesia. Hanya LINE saja yang berumur kurang dari 5 tahun di pasar digital Indonesia. Memasukan produk atau brand kedalam sebuah program TV atau film akan memiliki keuntungan dari segi waktu dan perhatian. Ini menjadi kelebihan tersediri dibandingkan beriklan secara spot. Penonton mempunyai peluang untuk menjadi captive audience di mana mereka seolah dipakasa melihat sebuah brand karena merupakan bagian dari isi cerita.

Tabel 1.3

Tahun Edar Merek di Indonesia

\begin{tabular}{|c|l|c|}
\hline No & \multicolumn{1}{|c|}{ Merek } & $\begin{array}{c}\text { Tahun Edar } \\
\text { di Indonesia }\end{array}$ \\
\hline 1 & Fuji Film & 1934 \\
\hline 2 & Garuda Indonesia & 1949 \\
\hline 3 & Mitsubishi & 1970 \\
\hline 4 & Aqua & 1973 \\
\hline 5 & L'oreal & 1979 \\
\hline 6 & Telkomsel & 1997 \\
\hline 7 & Lenovo & 2004 \\
\hline 8 & Magnum & 2008 \\
\hline 9 & LINE & 2013 \\
\hline
\end{tabular}


Dengan usia yang masih muda, LINE justru menjadi merek pertama yang bekerjasama dengan Miles Films dalam mempromosikan AADC 2 melalui pembuatan film pendek. Film pendek ini sekaligus memperkenalkan fitur baru LINE saat itu yakni Find Alumni. Hal ini tentu menunjukkan bahwa, Miles Films mampu mengidentifikasi dan menggunakan keampuhan dunia digital saat ini.

Entertainment branding adalah hal baru di dunia pemasaran serta branding yang dilakukan oleh perusahaan-perusahaan. Cara ini ditempuh sebagai salah satu pilihan untuk menyatukan dunia periklanan dengan dunia hiburan terutama film, di mana sebuah pesan merek diintegrasikan dengan konteks yang tepat sebagai bagian dari interaksi. Meskipun masih hal baru, namun sudah banyak perusahaan yang mencoba salah satu contohnya yakni keterlibatan para sponsor AADC 2. Iklan berlangsung bersamaan dengan berjalannya cerita film. Penonton akan ikut alur cerita dari film tersebut tanpa harus merasa bahwa ia sedang di branding.

Sedangkan dari sisi pola perilaku konsumen yang dibentuk karena adanya kemajuan program komunikasi pemasaran, peneliti melihat bahwa adanya perkembangan dalam sisi konsumen dalam merespon sesuatu. Pola konsumen pada masa lalu menyebutkan bahwa masyarakat yang melakukan pembelian ulang tentu sudah melakukan pembelian dengan hal yang sama sebelumnya, dan jika masyarakat sudah melakukan pembelian ada kemungkinan untuk melakukan pembelian ulang. Namun di masa sekarang, konsumen yang melakukan pembelian di film AADC 2 ternyata belum tentu konsumen yang melakukan pembelian pada film AADC 1 di waktu film pertama meluncur pada tahun 2002. Pola konsumen terbaru inilah yang disebut customer path 5A, yang merupakan hasil survey dari Markplus Inc oleh Herman Kartajaya.

Customer path 5A menjadi pertimbangan penelitian ini karena konsep customer path $5 \mathrm{~A}$ dilatarbelakangi dengan adanya konektivitas pada setiap individu sehingga akan mempengaruhi keputusan pembelian terhadap produk dari sebuah brand. Perlu digarisbawahi, meskipun konsep customer path 5A merupakan konsep atau acuan bagi pemasar namun peneliti menggunakan konsep tersebut dengan perspektif yang berfokus pada customer yaitu responden yang telah menonton AADC 2 . Unsur-unsur 5A yaitu aware, appeal, ask, act, dan advocate merupakan perilaku yang dilakukan oleh seorang individu sehingga pola perilaku pembelian oleh penonton AADC 2 dapat dianalisis dengan menggunakan customer path 5A.
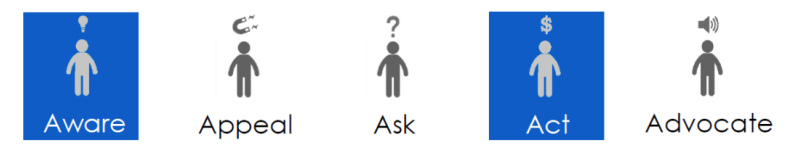

Sumber : marketeers.com

Customer path $5 \mathrm{~A}$ berasal dari fenomena internet dan gadget yang telah mempengaruhi kehidupan banyak orang (Bachdar, 2015). Tepatnya pada bulan April tahun 2014, Hermawan Kartajaya mencetuskan customer path terbaru yaitu konsep 5A yang terdiri dari Aware, Appeal, Ask, Act, dan Advocate, menggantikan tahapan konsumen $4 \mathrm{~A}$ yang 
terdiri dari Aware, Attitude, Act, dan Act Again yang secara umum digunakan oleh hampir seluruh sektor industri (Bachdar, 2015). Sejak tahun 2015, terdapat konektivitas ask-advocate antara customer yang bertanya dengan customer yang menjawab dengan rekomendasi namun konektivitas ini ternyata tidak imbang, seringkali lebih banyak yang bertanya ketimbang yang merekomendasikan sebuah merek. Arah konektivitas ini akan berubah bagus apabila merek direkomendasikan positif dan akan berubah buruk jika merek direkomendasikan dengan negatif.

Pola konsumen yang terjadipun berubah, dimana setidaknya ada lima tahap penerimaan konsumen terhadap suatu merek yakni Aware, pada tahap ini, konsumen pertama kali mengetahui tentang merek suatu perusahaan. Bagus sekali bila konsumen sudah mengetahui informasi dengan lengkap, tapi sering kali konsumen hanya mengetahui sebagian informasi mengenai merek tersebut. Lalu darimana konsumen akan mengetahui informasi lain dari merek tersebut? Pertama, customer mengenali merek dari aktivitas komunikasi pemasaran misalnya melalui iklan, pengenalan melalui sumber pertama ini adalah yang paling dangkal pengaruhnya bagi customer. Kedua, melalui rekomendasi komunitas, ini seringkali lebih mengena kepada customer. Ketiga, melalui pengalaman sendiri, umumnya karena sudah pernah menggunakan merek sebelumnya. Melalui pengalaman sendiri adalah yang paling besar pengaruhnya bagi customer, Top of mind awareness (TOM) biasanya bersumber dari pengalaman customer menggunakan merek tertentu. Kedua adalah Appeal, pada tahap ini, konsumen mulai tertarik dengan pelayanan dari merek perusahaan. Setelah di tahapan pertama konsumen terpikir terhadap merek tersebut, selanjutnya konsumen akan melakukan seleksi. Merek yang tidak menarik akan dilupakan dan yang menarik akan dipertimbangkan lebih lanjut. Ketiga adalah Ask, Pada tahap ketiga ini, konsumen sudah antusias pada suatu merek, tetapi mereka ingin mendapatkan informasi lebih dalam lagi sebelum melakukan pembelian. Tujuannya agar mereka semakin yakin akan merek tersebut. Konsumen lebih memilih untuk mendapatkan informasi dari pihak lain, apalagi dengan semakin mudahnya komunikasi melalui jalur elektronik terutama internet. Bertanya bisa dengan chatting lewat smartphone, bisa lewat email, bahkan melalui media sosial. Sebagai pihak perusahaan suatu merek, yang terpenting adalah konsumen dapat merasa terlayani dengan semaksimal mungkin. Tahap ini adalah tahap terakhir sebelum konsumen benar-benar melakukan pembelian. Keputusan untuk melakukan pembelian atau tidak ditentukan dari 'jawaban' yang didapat selama proses bertanya ini. Keempat adalah Act, Ini adalah tahapan dimana tenaga pelayanan merek memegang peranan paling penting. Tahap ini juga menjadi momen interaksi paling intensif yang terjadi antara konsumen dan perusahaan. Dalam hal ini , yang lebih penting lagi adalah sebagai pihak perusahaan, harus bisa membedakan mana yang membeli dan mana yang menggunakan produk Anda. Di sinilah engagement tingkat tinggi 
antara merek dan customer terjadi. Sekarang, interaks tidak hanya sebatas informasi, tetapi sudah masuk ranah physical interaction. Tahap terakhir adalah advocate, Dalam tahap ini ada 3 tingkatan loyalitas konsumen. Tingkat 1 jika konsumen tetap menggunakan merek tersebut yang disebut dengan retention. Tingkat 2 jika konsumen melakukan pembelian kembali yang disebut dengan repurchase. Tingkat tertinggi adalah ketika konsumen rela mempertaruhkan reputasi pribadinya untuk merekomendasikan merek tersebut. Tahap ini disebut loyalty yang sama dengan advocacy.

Seiring berjalannya pengalaman dalam mengkonsumsi merek, maka customer tidak akan segan untuk merekomendasikan merek tersebut pada orang lain terlebih lagi semakin customer ter-WOW, semakin besar peluang mereka sampai ke tingkatan ketiga. Advocacy pun juga dapat berupa advocacy spontan dan tidak spontan. Advocacy spontan terjadi ketika customer secara aktif akan merekomendasikan sebuah merek. Lain halnya dengan advocacy tidak spontan, biasanya advocacy ini terjadi ketika customer diberi pertanyaan terlebih dahulu kemudian merekomendasikan. Hermawan Kartajaya mengatakan bahwa advocacy spontan adalah yang terbaik.

Dalam penelitian ini, customer path 5A akan digunakan untuk melihat bagaimana sponsorhisp dalam film ini bisa merubah pola hidup masyarakatnya. Dalam hal ini mengignat iburan menjadi salah satu kebutuhan masyarakat. Saat masyarakat mencari hiburan dan menikmatinya, akan lebih mudah bagi sebuah merek untuk masuk kedalam pikiran konsumen tersebut tanpa merasa dipaksa. Branding melalui industri hiburan dapat membantu memperkuat citra sebuah brand. Dalam hal penyampaian kontenpun menjadi simbiosis mutualisme dikarenakan baik secara konten dan kebutuhan penonton sama-sama saling bisa menerima tanpa ada rasa keterpaksaan. Salah satu entertainment branding yakni insertion pada film yang dilakukan di film AADC 2.

Ada 9 merek yang beruntung menjadi sponsor dan sukses melaksanakan aktivitas branding sepanjang film yakni Aqua, L'oreal, LINE, Lenovo, Magnum, Mitsubishi, Garuda Indonesia, Telkomsel dan Fujifilm.

Berdasarkan latar belakang tersebut, peneliti tertarik untuk meneliti lebih lanjut mengenai pola konsumen yang dibentuk oleh konsumen baru dari branding 9 merek yang menjadi sponsor film AADC 2 sekaligus berkaitan dengan medium yang digunakan untuk mencari informasi film serta ketertarikan akan merek yang muncul sepanjang cerita film. Maka dari itu peneliti mengangkat tentang “Analisis Customer Path 5A Pada Sembilan Merek Sponsor Film Ada Apa Dengan Cinta 2 Sebagai Program Entertainment Branding"

\section{METODE PENELITIAN}

Denzin \& Lincoln mendefinisikan paradigma sebagai: "Basic belief system or worldview that guides the investigator, not only in choices of method but in ontologically and epistomologically fundamental ways" yang artinya adalah sistem keyakinan dasar atau cara memandang dunia 
yang membimbing peneliti tidak hanya dalam memilih metoda tetapi juga cara-cara fundamental yang bersifat ontologis dan epistomologis. Paradigma yang digunakan dalam penelitian ini yakni paradigma konstruktivisme. Paradigma konstruktivisme didefinisikan sebagai paradigma yang meletakkan pengamatan dan objektivitas dalam menemukan realitas atau ilmu pengetahuan. Paradigma ini memandang ilmu sosial sebagai analisis sistematis terhadap socially meaningful action melalui pengamatan langsung dan terperinci terhadap pelaku sosial yang bersangkutan menciptakan dan memelihara atau mengelola dunia sosial mereka (Hidayat, 2003: 3). Peneliti menggunakan paradigma konstruktivisme, karena peneliti ingin mengkonstruksi makna dan interpretasi aktivitas yang dilakukan oleh subjek. Subjek penelitian adalah responden yang menonton film Ada Apa Dengan Cinta 2 namun tidak menonton Ada Apa Dengan Cinta 1 ataupun baru menonton saat mengetahui akan ada kelanjutan filmnya. Menurut Guba (1990:27), sistem keyakinan dasar pada peneliti konstruktivisme, salah satu nya adalah Epistomogy. "Epistomogy is subjectivist inquirer and inquired into are fused a single (monistic) entity. Findings are literally the creation of the process of interaction between the two" Epistomogy merupakan subjektif peneliti dan yang diteliti disatukan ke dalam pengetahuan yang utuh dan bersifat tunggal (monistic). Pandangan peneliti bersifat subjektif dalam proses interaksi antara peneliti dengan subjek yang diteliti sehingga setiap jawaban subjek yang dilakukan menghasilkan makna oleh pemikiran peneliti dan kreasi dari proses interaksi tersebut. Dalam pandangan konstruktivisme, Ardianto dan Anees (2007:151) menjelaskan bahwa bahasa tidak hanya dilihat sebagai alat untuk memahami realitas objektif belaka dan dipisahkan dari subjek sebagai penyampai pesan. Konstruktivisme justru menganggap subjek sebagai faktor sentral dalam kegiatan komunikasi serta hubungan-hubungan sosialnya. Setiap pernyataan pada dasarnya adalah tindakan penciptaan makna, yakni tindakan pembentukan diri serta pengungkapan jati diri sang pembicara. Oleh karena itu, dalam analisis ini peneliti berusaha mengungkapkan customer path yang terbentuk dari responden yang merupakan penonton baru film Ada Apa Dengan Cinta.

Metode penelitian yang digunakan dalam penelitian ini adalah metode penelitian deskriptif kualitatif. Metode kualitatif merupakan penelitian yang bermaksud untuk memahami fenomena tentang apa yang dialami oleh subjek penelitian secara holistik, dan dengan cara deskripsi dalam bentuk kata-kata dan bahasa, pada suatu konteks khusus yang alamiah dan dengan memanfaatkan berbagai metode ilmiah (Moleong, 2007:6). Penelitian kualitatif ini dapat digunakan untuk memahami interaksi sosial, misalnya dengan wawancara mendalam sehingga akan ditemukan pola-pola yang jelas. Dan penelitian kualitatif adalah salah satu metode untuk mendapatkan 
ProTVF, Volume 2, Nomor 1, Maret 2018, Hal. 69-86

kebenaran dan tergolong sebagai penelitian ilmiah yang dibangun atas dasar teori teori yang berkembang dari penelitian dan terkontrol atas dasar empirik. Jadi dalam penelitian kualitatif ini bukan hanya menyajikan data apa adanya melainkan juga berusaha menginterpretasikan korelasi sebagai faktor yang ada yang berlaku meliputi sudut pandang atau proses yang sedang berlangsung.

\section{Objek dan Subjek Penelitian}

\section{Subjek Penelitian}

Subjek dalam penelitian ini yaitu responden yang telah mengisi kuesioner prapenelitian. Peneliti memilih responden dengan kriteria secara spesifik yakni :

- Telah menonton film Ada Apa Dengan Cinta 2

- Telah menonton film Ada Apa Dengan Cinta 1 setelah mengetahui akan ada film Ada Apa Dengan Cinta 2 atau,

- Responden yang tidak menonton Ada Apa Dengan Cinta 1

\section{Objek Penelitian}

Customer path dari pengetahuan dan kesadaran akan sembilan sponsor yang ada di sepanjang film Ada Apa Dengan Cinta 2 di kalangan penonton baru menjadi objek penelitian bagi peneliti. Film Ada Apa Dengan Cinta adalah salah satu film Indonesia terpopular sepanjang masa. Kehadirannya pada tahun 2002 silam masih menyisakan kenangan yang membuat Miles Films memutuskan untuk membuat kelanjutannya. Antusiasme ini tentu disambut meriah, bukan hanya dari para penonton film sebelumnya, namun juga masyarakat Indonesia yang belum mengenal namun terpengaruh

oleh ramainya perbincangan film ini.

\section{HASIL DAN PEMBAHASAN}

\section{Customer Path 5A}

\section{Tahap Aware}

Berdasarkan hasil penelitian akan pernyataan tersebut, maka dapat ditarik kesimpulan dari tiga aspek diatas :

a. Dari sisi komunikasi pemasaran AADC 2 sudah membangun pengetahuan yang baik dari segi 7P yang mencakup place, price, promotion, product, people, physical environment, dan process (Schiffman \& Kanuk, 1994:242).

b. Dari sisi respon, ketertarikan akan AADC 2 kurang diimbangi dengan perhatian yang lebih terhadap pesan yang ingin disampaikan oleh 9 merek sponsor ini (Kotler \& Keller, 2009:179).

c. Dan yang terakhir dari sisi perilaku konsumen yang bersifat dinamis. Artinya, usaha dalam memberikan pengetahuan mengenai AADC 2 tidak disertai dengan pemberian pengetahuan mengenai sponsor yang ada didalamnya juga (Nugroho J. Setiadi, 2008:3).

Jika dikaitkan dengan customer path $5 A$, pada tahap pertama yakni aware, ketiga informan mampu menyadari dan sadar betul mengenai kehadiran merek sponsor. Kesadaran akan merek inilah yang akan menghantarkan informan kepada tahap selanjutnya, apakah informan tertarik dengan merek sponsor tersebut ataukah tidak (Kartajaya, 2015:85). 


\section{Tahap Appeal}

Ketiga informan utama memiliki pendapat yang sama ketika ditanya alasan menonton AADC 2 yakni rasa penasaran dan keingintahuan yang tinggi meskipun tidak menonton AADC 1. Hal ini menjelaskan bagaimana kuatnya rasa tertarik informan dengan keberadaan film AADC 2. Hal ini juga didukung oleh pendapat informan pendukung yang menjelaskan bahwa AADC 2 memanfaatkan adanya ingatan yang kuat tentang sekuel sebelumnya yakni AADC 1. Lingkungan sekitar yang terus membicarakan mengenai sekuel film ini, membuat akhirnya informan utama yang tidak menonton ikut tergugah untuk menonton AADC 2 ((Littlejohn \& Foss, 2005: 72-73).

Namun, ketertarikan akan film AADC 2 kurang didukung oleh ketertarikan akan merek sponsor yang ada. 1 dari 3 informan mengaku tertarik dengan salah satu merek sponsor yang ada. Sedangkan sisanya, mengaku tertarik namun bukan karena terpaan dari adanya merek sponsor di film tersebut. Jika dikaitkan dengan customer path $5 A$, tahap kedua yakni appeal dapat dikatakan kurang baik. Karena, hanya 1 dari 3 informan yang tertarik salah satu merek sponsor AADC 2 yang diakibatkan oleh insertion pada film tersebut. Tahap appeal ini menjelaskan bahwa informan akan tertarik pada suatu hal atau spesifiknya merek sponsor namun masih dalam kategori belum yakin. Artinya, ketertarikan informan akan membawa informan kepada tahap selanjutnya pada customer path $5 \mathrm{~A}$ (Kartajaya, 2015:87).

\section{Tahap Ask}

Ketiga informan utama memiliki pendapat yang berbeda-beda saat ditanya mengenai referensi yang digunakan sebelum menonton AADC 2. 2 dari 3 informan utama memilih untuk bertanya kepada kerabat yang memang sudah menonton AADC 2 tersebut. Sisanya memilih untuk mencari tahu sendiri informasi yang ingin didapatkan.

Menurut customer path $5 \mathrm{~A}$, seseorang yang tertarik akan sesuatu pasti akan masuk ke tahap selanjutnya yakni ask. Namun, bukan berarti pula calon konsumen yang tidak tertarik tidak mencari tahu lebih lanjut mengenai suatu merek, hal ini ditujukan hanya sebatas untuk menambah wawasan bagi calon konsumen itu sendiri. Hal ini terlihat dari jawaban informan utama yang sudah peneliti cantumkan pada detil informasi sebelumnya. 2 dari 3 informan utama mengaku mencari tahu lebih lanjut mengenai merek tersebut.

Tahap ask merupakan peralihan dari proses individual ke sosial, customer kemudian aktif mencari informasi mengenai merek tersebut baik secara online maupun offline, atau melalui rekomendasi komunitasnya karena kurang yakin pada merek yang ada di tahap appeal tentu masih terbawa. Pencarian yang mungkin dilakukan di internet seperti di blog yang ditulis oleh orang lain, situs website produk pembanding, 
dan halaman web resmi perusahaan, atau dengan berbicara dengan keluarga atau teman-teman yang telah menggunakan produk atau layanan. Konsumen kemudian membuat keseluruhan pendapat berdasarkan informasi yang dikumpulkan dan informasi yang disajikan oleh perusahaan dengan mempertimbangkan komentar dan opini dari orang-orang yang telah membeli dan menggunakan produk atau layanan yang ditawarkan oleh sebuah merek. Keputusan customer membeli atau tidak, akan ditentukan berdasarkan "jawaban” yang diterima dari proses bertanya-tanya ini.

Tahap ini menjadi sangat penting karena pada tahap ini menjadi salah satu tahap yang menentukan apakah konsumen akan melakukan pembelian atau tidak. Hal ini juga didukung oleh salah satu informan pendukung, Mas Mercy Tahitoe yang menjelaskan bahwa tahap ini adalah tantangan bagi perusahaan untuk mampu memenangkan hati calon konsumen.

Jika dikaitkan dengan customer path $5 A$, tahap ketiga yakni ask dikategorikan cukup baik. Keingintahuan informan utama dalam mencari informasi mengenai film AADC 2 diimbangi dengan kemampuan dan keinginan informan dalam mencari informasi dengan baik mengenai salah satu merek sponsor film AADC 2 tersebut. Sedangkan informan lainnya memilih untuk tidak mencari informasi lebih jauh karena memang sudah mengenal baik akan merek yang diingatnya tersebut (Kartajaya, 2015:89).

\section{Tahap Act}

Tahap act ini dapat dikategorikan menjadi dua bagian :

\section{a. Act Positif}

Aksi yang dilakukan konsumen akan berdampak positif jika konsumen melakukan pembelian atas merek sponsor tersebut. Namun, aksi yang mengarah ke arah positif belum tentu memberikan hasil yang positif juga pada tahap akhir dari customer path 5A. Aksi positif ini kemungkinan besar diakibatkan karena calon konsumen tidak kesulitan dalam mencari informasi, informasi yang didapatkan jelas, dan mendapatkan informasi tersebut dari sumber yang terpercaya.

b. Act Negatif

Aksi yang mengarah ke arah negatif artinya calon konsumen tidak melakukan pembelian setelah mencari dan mendapatkan informasi pada tahap ask sebelumnya. Aksi negatif ini bisa saja disebabkan karena beberapa hal seperti kurangnya informasi yang diperlukan, kurang credible nya orang yang member rekomendasi, ketidaktertarikan yang timbul dari diri sendiri ataupun adanya kekurangan dari segi perusahaan. Konsumen yang melakukan aksi negatif belum tentu tidak terlibat dalam tahap terakhir customer path 5A. Konsumen ini bisa saja menjadi orang yang dimintai rekomendasi apakah produk dari merek sponsor tersebut baik atau tidak. 
Seperti yang sudah dijabarkan peneliti pada karakteristik informan utama, seluruh informan utama adalah informan yang sudah menonton AADC 2, dalam arti seluruh informan utama melakukan aksi positif dalam konteks film AADC 2. Namun jika ditelaah dari segi merek sponsor film AADC 2, maka konteksnya akan sedikit berbeda.Pada tahap ask sebelumnya ada 2 informan yang mencari tahu lebih lanjut mengenai merek sponsor yang mereka ingat. Dan di tahap act ini, kedua informan tersebut melakukan aksi positif dengan melakukan pembelian atau penggunaan terhadap merek sponsor tersebut. Hal ini membuktikan bahwa informan mendapatkan informasi yang positif pada tahap sebelumnya sehingga tergugah untuk melakukan pembelian ataupun penggunaan terhadap merek sponsor tersebut.. Hal ini dibuktikan dari pernyataan dua informan utama yang memang melakukan pembelian atau pemakaian pada merek yang mereka ingat. Pada tahap act apabila hasil calon konsumen mencari informasinya positif maka calon konsumenpun akan menjadi yakin bahwa suatu merek memang layak untuk mereka, maka mereka membeli dan menggunakan merek tersebut. Jika teman dan keluarga bilang bagus, barulah calon konsumen memutuskan untuk menggunakan produk dari merek tersebut. Keyakinan dan rekomendasi positif orang lain menjadi bekal konsumen untuk memutuskan pembelian. Pada tahap ini, proses engagement antara merek dengan konsumen akan terjadi jika timbul masalah di tahap ini, seperti masalah teknis atau masalah realitas yang tidak sesuai janji yang diberikan oleh merek dan membuat konsumen komplain. Penanganan merek terhadap komplain merupakan interaksi terpenting, ketika merek dapat memberikan solusi maka akan terjadi momen WOW dari konsumen.

Jika dikaitkan dengan customer path $5 A$, tahap keempat yakni act dikategorikan cukup baik. Aksi positif yang dilakukan informan utama dalam menonton film AADC 2 diimbangi dengan aksi positif terhadap merek sponsor film tersebut (Kartajaya, 2015:92).

\section{Tahap Advocate}

Tahap terakhir dari customer path 5A yakni advocate. Pada tahap ini terbagi menjadi 3 sub-tahap yakni retention, repurchase dan advocacy. Berdasarkan hasil penelitian, ketiga informan utama yang sudah pasti menonton AADC 2 memiliki jawaban berbeda. Dalam konteks film AADC 2, hanya 1 dari 3 informan yang memilih untuk mau menonton ulang dan 2 dari 3 informan yang memilih untuk merekomendasikan film AADC 2 ini kepada orang lain.

Sedangkan, dari segi merek sponsor 2 dari 3 informan memilih untuk menggunakan atau membeli produk dari merek sponsor 
ProTVF, Volume 2, Nomor 1, Maret 2018, Hal. 69-86

seperti yang telah dijelaskan pada tahap act yang juga sekaligus menjelaskan sub-tahap retention. Pada sub-tahap repurchase ada 2 dari 3 informan yang bersedia untuk melakukan pembelian atau penggunaan ulang terhadap produk tersebut, dan dari subtahap advocacy, seluruh informan utama bersedia untuk merekomendasikan merek sponsor yang merek ingat kepada orang lain.

Zaman sekarang ini, yang diinginkan perusahaan suatu produk atau jasa bukan hanya sekedar pembelian dari konsumen, melainkan rekomendasi kepada calon konsumen lainnya. Rekomendasi positif atau negatif dapat diterima oleh calon konsumen jika ia merasa orang yang memberikan rekomendasi credible.

Jika dikaitkan dengan customer path 5A, tahap kelima yakni advocate dikategorikan baik. Ketiga informan utama sudah mencapai sub-tahap advocacy yang artinya mau merekomendasikan merek sponsor yang mereka tahu kepada orang lain atau calon konsumen. (Kartajaya, 2015:98).

\section{Entertainment Branding}

Ketiga informan utama hanya mampu mengingat 1 hingga 2 merek sponsor AADC 2 dengan benar. Dipandang dari sisi perusahaan, maka hal ini justru berdampak buruk. Terlebih lagi bagi beberapa merek yang mendapat jumlah scene lebih banyak dibandingkan merek yang lain, tentunya ingin mendapatkan awareness yang lebih.

Seperti yang diungkapkan oleh informan pendukung, 9 sponsor film AADC 2 tentu mengharapkan adanya branding, meskipun merek perusahaan tersebut telah lama berada di Indonesia. Namun jika melihat hasil wawancara dengan informan utama, tentu entertainment branding yang dilakukan melalui insertion pada film dianggap kurang berhasil, hal ini juga didukung oleh pernyataan informan pendukung. Selain itu, dapat dilihat jumlah scene lebih banyak didapat oleh Lenovo, namun merek sponsor yang diingat justru seperti Garuda, LINE dan juga L'oreal. Hal ini menunjukkan bahwa untuk mendapatkan awareness dan ingatan yang jelas di benak konsumen, tidak bisa hanya berasal dari satu terpaan saja. Garuda, LINE dan L'oreal bisa saja sudah membentuk ingatan yang baik di benak konsumen sebelumnya, sehingga walaupun melihat hanya sekilas audiens sadar betul dengan merek sponsor tersebut.

Melalui penelitian ini pula, peneliti menemukan adanya kecenderungan bahwa film AADC 2 justru lebih melakukan destination branding atau mempromosikan Provinsi DIY Yogyakarta atau spesifiknya objek wisata yang ada di daerah Yogyakarta dan Jawa Tengah. Hal ini dapat dilihat dari beberapa jawaban informan utama yang sebagian besar mengingat adegan adegan film khususnya yang ada selama di Yogyakarta. Tak luput juga didukung oleh beberapa informasi dari informan pendukung.

Dalam melakukan entertainment branding ini ada bebrapa yang peneliti amati dimana peneliti melihat adanya tujuan branding produk namun dari hasil penelitian ini audience lebih ingat pada kota. Dalam hal ini tujuan branding harus jelas dimana hal ini diperlukan untuk mendukung upaya pemasaran. Dalam hal ini 
juga bisa digunakan untuk mengembangkan kesadaran merek yang kuat akan keberadaan sebuah brand dalam benak seseroang.

Entertainment branding tentunya tidak bisa dipisahkan dari kegiatan komunikasi pemasaran memfasilitasi proses pertukaran dan pengembangan hubungan dengan konsumen dengan cara mengamati secara cermat kebutuhan dan keinginan konsumen yang dilanjutkan dengan mengembangkan suatu produk (product) yang memuaskan kebutuhan konsumen dan menawarkan produk tersebut pada harga (price) tertentu serta mendistribusikannya agar tersedia di tempattempat (place) yang menjadi pasar bagi produk yang bersangkutan. Untuk itu perlu dilaksanakan promosi (promotion) atau komunikasi guna menciptakan kesadaran dan ketertarikan konsumen kepada produk bersangkutan. Proses ini disebut marketing mix atau bauran pemasaran yang disingkat dengan 'empat P' (Morissan, 2010: 5). Namun kini, selain 'empat $\mathrm{P}$ ' adalah elemen lain yang harus ditambahkan yakni 3P yang mencakup proses (process), sarana fisik (physical environment), dan orang (people). Kotler dan Amstrong (2012:62) menjelaskan bahwa 3P ini juga berpengaruh dalam proses pemasaran kepada konsumen. Walaupun konsumen tidak mengetahui secara langsung proses yang terjadi, namun proses sangat berpengaruh terhadap keberhasilan suatu pemasaran. Begitu pula dengan orang dan sarana fisik.

\section{SIMPULAN}

Customer path $5 \mathrm{~A}$ melewati tahap-tahap mulai dari aware, appeal, ask, act dan advocate. Pada tahap aware, merek-merek sponsor yang hadir pada film ini sudah mampu meraih perhatian dan kesadaran dari ketiga informan utama. Namun, pada tahap selanjutnya yakni appeal hanya satu informan utama saja yang tertarik dengan merek sponsor yang diingat. Pada tahap ask, tidak hanya informan yang tertarik namun informan yang sudah memiliki pengetahuan awal juga ikut mencari informasi lebih dalam mengenai merek-merek sponsor yang diingat. Sedangakan, ada informan utama yang tidak mencari tahu karena sudah memiliki informasi yang cukup. Pada tahap keempat yakni act, menunjukkan bahwa informan utama yang mencari tahu informasi melakukan act yang ke arah positif. Pada tahap advocate, perlu adanya usaha lebih yang dilakukan oleh merekmerek sponsor tersebut untuk melakukan pendekatan lain karena berdasarkan hasil penelitian, informan utama yang tidak tertarik sebelumnya masih bisa dipengaruh untuk melakukan engagement pada produk dan mau untuk merekomendasikan merek sponsor tersebut kepada orang lain. Perilaku konsumen bersifat dinamis. Itu berarti bahwa perilaku seseorang konsumen, grup konsumen, ataupun masyarakat luas selalu berubah dan bergerak sepanjang waktu. Hal ini memiliki implikasi terhadap studi perilaku konsumen, demikian pula pada pengembangan strategi pemasaran (Nugroho J. Setiadi, 2008:3). 
ProTVF, Volume 2, Nomor 1, Maret 2018, Hal. 69-86

Berdasarkan hasil pengamatan, pada dasarnya entertainment branding pada film AADC 2 bukan hanya fokus kepada merekmerek sponsor saja, karena merek sponsor yang hadir berbaru dengan latar belakang atau setting dan jalan cerita film tersebut. Sehingga hal ini membuat ketertarikan dari sisi lain yakni destination branding.

Kotler dan Pfoerstch (2006:10) dalam Bungin (2015; 78) menjelaskan bahwa branding memiliki beberapa azas yang perlu dijadikan pegangan diantaranya Konsistensi, Merupakan aturan brand yang paling penting bagi suatu produk. Ini menyangkut semua dimensi pada suatu produk termasuk juga saluran pemasaran, cara staff melayani pelanggan, tanggung jawab sosial bahkan perencanaan investasi. Kejelasan ,merupakan keunikan dan memiliki relevansi bagi keputusan wisatawan. Kontinuitas, Dalam hal ini destinasi tidak boleh merubah brand karena brand yang kuat adalah brand yang dikenal terus menerus. Brand harus mampu dikenal dan tidak lapuk dimakan waktu Visibilitas, Pada kasus tertentu visibilitas akan brand akan mendukung citra brand dimata wisatawan dan menjadi penting untuk mencapai mindshare destination brand yang lebih besar bagi pariwisata., Authentisitas.

Merupakan arahan kepada pemikiran dan tindakan setiap orang pada sebuah brand destinasi dengan fokus menciptakan orisinalitas dan perasaan pada wisatawan untuk memiliki, menggunakan atau melakukan pencarian unik walaupun tanpa disadarinya.
Mengembangkan penelitian kearah entertainment branding dengan dihubungkan pada destination branding melalui film.

Mengembangkan penelitian destination branding pada konsumen antar generasi.

Memperjelas tujuan branding, dimana setiap upaya pemasaran harus dimulai dengan tujuan yang jelas. Apakah Anda ingin meningkatkan pembelian untuk produk baru? Apakah Anda ingin mengembangkan kuat kesadaran merek dalam demografis tertentu? Luangkan waktu sejenak untuk secara khusus menguraikan tujuan dan sasaran sebelum bergerak maju.

Saran bagi praktisi, untuk tidak meninggalkan entertainment branding tanpa terpaan lain dari kegiatan komunikasi pemasaran lain, karena sifat audiens bersifat captive (menyatu pada jalan cerita).

Entertainment branding pada film melalui insertion pada film harus fokus pada merek sponsor tertentu agar memunculkan identical product yang membuat audiens lebih fokus pada merek tersebut.

Pemasar harus mengatur sesi brainstorming dengan tim suksesnya untuk melakukan upaya branding

Pemasar buat Konten untuk diluncurkan, tentunya akan sulit bila konten produksi Anda masih memiliki standar yang kurang baik, oleh Karena itu ada beberapa hal yang harus dipertimbangan dalam mencari tim yang baik. Kualifikasinya adalah mampu menjadi storyteller yang baik, Berperestasi dalam hal pembuatan video dan memiliki pengalaman dengan penanganan brand entertainment. 
Melaukan 7 proses branding seperti yang diungkapkan oleh Baker (2007; 78) dalam Bungin $(2015$; 78) yaitu pemasar melalukan Assesmen dan Audit Di mana destinasi itu berada yang mana brand tersebut memperkenalkannya. Perlunya Analisis dan Keuntungan dimana nlai lebih apa yang diberikan suatu destinasi ketika di banding melalui film . Posisi brand, Bagaimanana hubungan brand yang digunakan dalam satu destinasi . Artikulasi Hal ini berkenaan dengan Bagaimana brand mengekspresikan visualisasi dan verbalisasi dalam iklan atau kampanye branding destinasi.

Pemasar juga kini bisa melakukan Aktivasi , Bagaimana brand mengaktivasi kehidupan yang lebih baik dengan sapaan, yaitu bagaimana membuat brand lebih baik. Perlu memperhatikan Adoopsi dan sikap, Intinya adalah bagaimana stakeholder suatu destinasi men-support brand destinasi dan Aksi dan sesudahnya, dalam hal ini adalah Bagaimana brand memberikan peluang terhadap pembukaan usaha produktif dalam dunia pariwisata pada sebuah destinasi setelah diperkenalkan melalui film.

\section{DAFTAR PUSTAKA}

Bungin, Burhan (2015). Pemasaran dan Brand Destinasi, Kencana, Jakarta 2015

Kartajaya, Hermawan. (2014.) WOW Marketing. Jakarta: Gramedia Pustaka Utama
Kartajaya, Hermawan.(2014). WOW Selling. Jakarta: Gramedia Pustaka Utama

Kartajaya, Hermawan. (2015). I Am Marketeers. Jakarta: Gramedia Pustaka Utama

Kotler, Philip, dan Kevin Lane Keller.(2009) Manajemen Pemasaran Jilid 1, Edisi Ketiga Belas, Terjemahan Bob Sabran, MM. Jakarta: Penerbit Erlangga

Kotler, Philip, dan Gary Armstrong. (2012). Prinsip-prinsip Pemasaran, Edisi Ketiga Belas,. Jakarta: Penerbit Erlangga

Littlejohn, Stephen W \& Karen A. Foss. (2005). Theories of Human Communication, (terj.). Jakarta: Salemba Humanika

Morissan. (2010). Periklanan: Komunikasi Pemasaran Terpadu. Jakarta: Prenada Media Group

Pamungkas, Indra Novianto Adibayu .( 2016). Brand0logy: Brand, Branding \& Brand Activation. Yogyakarta: Deepublish

Rangkuti, Freddy (2009). Strategi Promosi yang Kreatif dan Analisis Kasus Integrated Marketing Communication. Jakarta: PT. Gramedia Pustaka Utama Setiadi, Nugroho J (2008). Perilaku Konsumen: Konsep dan Implikasi untuk Strategi dan Penelitian Pemasaran. Jakarta: Prenada Media Group 